\title{
Een transitievergoeding na een terecht gegeven ontslag op staande voet?
}

prof. mr. Evert Verhulp*

\section{Inleiding}

Onder het oude recht overwoog de Hoge Raad dat een terecht gegeven ontslag op staande voet niet kennelijk onredelijk kon zijn. Dat oordeel sluit aan bij het rechtsgevoel: het 'voelt' niet goed dat de werkgever die de werknemer terecht op staande voet heeft ontslagen toch aan die werknemer een transitievergoeding zou moeten betalen.

$\mathrm{Na}$ de invoering van de $\mathrm{W} w z$ kan de werkgever die de werknemer terecht op staande voet ontslaat, toch de transitievergoeding verschuldigd zijn. Naar huidig recht is de werkgever de transitievergoeding verschuldigd als het eindigen van de arbeidsovereenkomst niet het gevolg is van ernstig verwijtbaar handelen of nalaten van de werknemer. Volgens de vaste rechtspraak geldt dat het ontstaan van een dringende reden niet zonder meer aan de werknemer te wijten hoeft te zijn, om hem toch rechtsgeldig op staande voet te kunnen ontslaan, laat staat dat van ernstige verwijtbaarheid sprake hoeft te zijn.

In deze bijdrage onderzoek ik of na de invoering van de Wwz nog reden is vast te houden aan de gedachte dat een werknemer geen verwijt hoeft te treffen van de dringende reden om hem terecht op staande voet te kunnen ontslaan. Indien aan die gedachte wordt vastgehouden, is de vraag of dan niet over en weer vorderingen ontstaan, want waar de werkgever de transitievergoeding aan de werknemer moet betalen, kan de werknemer aan de werkgever de gefixeerde schadevergoeding moeten betalen. De werknemer die door opzet of schuld aan de werkgever een dringende reden heeft gegeven is immers, als de werkgever van die dringende reden gebruik heeft gemaakt om de arbeidsovereenkomst onverwijld op te zeggen, aan die werkgever een schadevergoeding verschuldigd (artikel 7:677 lid 2 BW).

\section{Geen verwijt aan de werknemer, toch een dringende reden?}

Uit de parlementaire geschiedenis volgt dat de regering in 1905 opzet en schuld onlosmakelijk verbonden achtte met de dringende reden. ${ }^{1}$ In de parlementaire behandeling die daarop volgde is dit punt uit het oog verloren en zijn ook voorbeelden van de dringende reden gegeven die niet zonder meer te herleiden zijn tot verwijtbaar gedrag van de werknemer. Vervolgens is ook in de rechtspraak de verwijtbaarheid van de werknemer geen vereiste gebleken om toch een dringende reden aan te nemen. Twee voorbeelden daarvan: de werknemer die in een overspannen toestand een stoel naar de bedrijfsarts gooit, geeft de werkgever een dringende reden, ook als hem vanwege de overspannenheid van het gooien geen verwijt te maken valt. ${ }^{2}$ Een tweede voorbeeld betreft de werkneemster die op staande voet wordt ontslagen vanwege een vechtpartij, waarbij haar stelling dat haar ter zake van het ontstaan van de vechtpartij geen verwijt kan worden gemaakt, als niet relevant wordt gepasseerd. ${ }^{3}$

Ik vraag me af of deze rechtspraak wel terecht is. Ligt het niet meer voor de hand aan te nemen dat indien de werknemer van het ontstaan van de toestand of omstandigheid die een dringende reden kan vormen, geen ernstig verwijt te maken valt, er geen sprake is van een dringende reden? Zondag neemt die vraag ook als uitgangspunt en onderzoekt in hoeverre de verwijtbaarheid een rol speelt bij het aannemen van een dringende reden. Hij wijst erop dat de rechter de verwijtbaarheid meeweegt bij de beoordeling van de dringende reden en dat de Hoge Raad kiest voor een pragmatische benadering, waarbij de vraag in welke mate de werknemer een verwijt kan worden gemaakt wel degelijk van belang blijft, maar niet afzonderlijk door de werkgever hoeft te

1. Zie hierover uitvoerig en naar mijn mening overtuigend: S.W. Kuip, Ontslagrecht met bijzondere aandacht voor de dringende reden, Deventer: Kluwer 1993, p. 49. Kritisch weer over deze opvatting van Kuip: S.F. Sagel, Het ontslag op staande voet, Deventer: Kluwer 2013, p. 299 e.v.

2. HR 3 maart 1989, NJ 1989/549 (Choaibi/NS), werknemer gooit in overspannen toestand een stoel naar de bedrijfsarts.

3. HR 19 juni 1987, NJ 1988/77 (Drop/Desouas), werkneemster treft geen verwijt van het ontstaan van een vechtpartij, toch een dringende reden aangenomen, zie ook HR 29 september 2000, JAR 2000/223 (D./Nutricia). 
worden bewezen. ${ }^{4}$ Hij concludeert, hoewel de gedachte dat een werknemer zonder dat hem de dringende reden kan worden verweten toch op staande voet kan worden ontslagen hem een gevoel van onbehagen geeft, dat de Hoge Raad niet 'om' hoeft. Sagel is sterker overtuigd van de juistheid van de rechtspraak vooral omdat 'verwijtbaarheid als conditio sine qua non voor ieder rechtsgeldig ontslag in de praktijk hoogst onwenselijke, niet uitlegbare effecten kan hebben'. ${ }^{5}$ Hij wijst erop dat in de rechtspraak wel geldt dat de verwijtbaarheid een belangrijk gezichtspunt kan zijn bij de beantwoording van de vraag of een bepaalde gedraging als dringend kan worden beschouwd. Sagel en Zondag hebben zeker een punt waar zij erop wijzen dat de Hoge Raad door deze overwegingen wegblijft bij de beoordeling of de werknemer overspannen is, of in een bepaalde geestestoestand verkeert, zodat hem geen of geen ernstig verwijt van het ontstaan van de dringende reden te maken valt en waartoe dat dan dient te leiden. Dat wegblijven bij een dergelijk onderzoek heeft voordelen nu het niet alleen buitengewoon lastig is daarvan een goede inschatting te maken en de werkgever voor behoorlijke bewijsproblemen kan stellen, maar ook nu wel heel feitelijk zal zijn en dus niet zonder meer in cassatie aantastbaar zal zijn. Ik kom hierop later terug, want het zal blijken dat door het ontslagrecht zoals dat geldt na invoering van de Wwz een dergelijk onderzoek nu juist wel nodig is.

In de jaren tachtig hebben twee A-G's geconcludeerd dat verwijtbaarheid wel moet worden betrokken bij de beoordeling van een dringende reden die is gestoeld op handelen en gedragingen, maar niet indien de dringende reden is gestoeld op eigenschappen. ${ }^{6}$ De Hoge Raad heeft die gedachte nooit overgenomen. Naar de opvatting van Sagel terecht: 'Met enige creativiteit - dan wel het inroepen van een psycholoog - kan elke gedraging wel worden gezien als een uiting van een (karak-

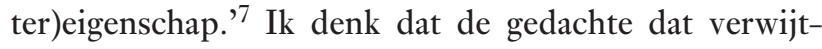
baarheid bij 'eigenschappen' niet vereist hoeft te zijn, onjuist is. Sterker nog: ik denk dat het ontslag op staande voet wegens eigenschappen op zichzelf weliswaar wel door de wetgever is voorzien, maar in de praktijk geen enkele waarde heeft. Een eigenschap kan leiden tot handelingen of gedragingen die de dringende reden vormen: eigenschappen die de werknemer nooit in daden of gedragingen omzet, niet. Anders gezegd: een ontslag op staande voet wegens een leugenachtige aard zie ik slechts voor me als de werkgever ook wegens het liegen zelf een dringende reden heeft.

Naar mijn mening is de verwijtbaarheid en de mate daarvan veelal makkelijker aan te nemen dan op het eer-

4. W. Zondag, 'De dringende reden en het ontbreken van verwijtbaarheid: wat te doen met het avas-verweer?' in: S.F. Sagel (red.), Vrienden door Dik en dun, Deventer: Kluwer 2011, p. 51.

5. S.F. Sagel, Het ontslag op staande voet, Deventer: Kluwer 2013, p. 300-301.

6. Hetgeen door zowel A-G Franx in zijn conclusie voor HR 22 januari 1982, NJ 1982/470 (Chemlal/Jaarbeurs), als door A-G Biegman-Hartogh voor HR 5 december 1986, NJ 1987/404 (X/Nederlandse Reassurantiegroep) en door A-G Mok voor HR 27 mei 1988, NJ 1988/73 (Den Hartogh/Luit) is bepleit.

7. S.F. Sagel, Het ontslag op staande voet, Deventer: Kluwer 2013, p. 301. ste gezicht lijkt. Duk beoordeelt al voordat de $\mathrm{Wwz}_{\mathrm{w}}$ in beeld is de juistheid van een reeks door de rechter behandelde ontslagen op staande voet aan de hand van de ernstige verwijtbaarheid van de werknemer. ${ }^{8}$ Mij lijkt het gooien van een stoel naar het hoofd van de bedrijfsarts, ook als de werknemer overspannen is en dat kan bewijzen, ernstig verwijtbaar. Als dat gooien door de overspannenheid van de werknemer anders moet worden gewaardeerd, is het de vraag of dan nog wel sprake is van een dringende reden. Het deelnemen aan een vechtpartij lijkt me evenzeer ernstig verwijtbaar, ook als de werkneemster bij het ontstaan van de vechtpartij geen (overwegend) verwijt te maken valt. Dat kan anders zijn als de werkneemster aantoont dat ze heeft geprobeerd een vechtpartij te voorkomen en zich heeft geprobeerd te onttrekken aan die gebeurtenissen. In het geval dat de werkneemster erin slaagt aan te tonen dat ze heeft getracht zich te onttrekken, ontbreekt naar mijn mening een rechtvaardiging voor een ontslag op staande voet. Of dit laatste voldoende in het recht is verankerd als de verwijtbaarheid slechts als 'een belangrijk uitgangspunt' geldt, maar niet als vereist voor het aannemen van een dringende reden, is de vraag, zodat ik aarzel bij de conclusies die Sagel en Zondag trekken. Ik denk dat de opvatting van Kuip, die schrijft: 'De arbeider behoort naar mijn mening dan ook minimaal in die zin te worden beschermd dat hij zijn werkkring niet op staande voet kan verliezen door daden, eigenschappen of gedragingen waaraan hij geen enkele schuld heeft', beter aansluit bij het rechtsgevoel en in de praktijk goed, en na de invoering van de Wwz zelfs beter, werkbaar kan zijn.

\section{Het ontslag op staande voet en een vergoeding}

Krachtens het oude recht (van voor de Wwz) kon een terecht gegeven ontslag op staande voet niet tevens kennelijk onredelijk zijn. De Hoge Raad overwoog dat met zoveel woorden in het arrest Schrijvers/Van Essen. De rechtbank meende dat het ontslag op staande voet terecht verleend was, maar omdat de werknemer bij het veroorzaken van de dringende reden geprovoceerd was door de dochter van de werkgever, achtte de rechtbank de opzegging tevens kennelijk onredelijk en kende de werknemer een vergoeding toe van $f$ 25.000. De Hoge Raad overwoog dat bij de beoordeling van de vraag of sprake was van een terecht aangevoerde dringende reden alle omstandigheden van het geval, in onderling verband en samenhang, in aanmerking moeten worden genomen. In de woorden van de Hoge Raad: 'De vraag of de gevolgen van de beëindiging van de dienstbetrekking voor de werknemer te ernstig zijn in vergelijking met het belang van de werkgever bij de beëindiging,

8. R.A.A. Duk, 'Hoe dringend is dringend', in: Sociaal Recht: Tussen behoud en vernieuwing, liber amicorum voor Antoine Jacobs, Zutphen: Paris 2011, p. 321. 
behoort derhalve te worden beantwoord in het kader van de vraag of sprake is van een dringende reden. ${ }^{9}$ Anders gezegd: indien de werknemer vanwege het ontslag op staande voet een vergoeding wegens kennelijke onredelijkheid zou toekomen, kan van een rechtsgeldig ontslag op staande voet geen sprake meer zijn.

De Hoge Raad heeft nog een tweede overweging om een terecht verleend ontslag op staande voet niet tevens kennelijk onredelijk te achten. Dit argument hangt samen met de schadeplichtigheid van de werknemer na een ontslag op staande voet. De Hoge Raad overweegt: 'Tenslotte verdient nog aantekening dat een verplichting van de werkgever tot schadevergoeding in geval van ontslag wegens een dringende reden op de grond dat beëindiging van de dienstbetrekking kennelijk onredelijk is om de in art. $1639 \mathrm{~s}$ lid 2 onder $2^{\circ}$ vermelde reden, zich niet laat verenigen met de in art. 1639 o lid 3 voorziene mogelijkheid dat de werknemer in geval van een ontslag wegens een dringende reden jegens de werkgever schadeplichtig is (...)'. Kern van de overweging is dat het vreemd zou zijn aan te nemen dat partijen na een terecht gegeven ontslag op staande voet over en weer een vergoeding aan elkaar verschuldigd zouden kunnen zijn: de werknemer zou schadeplichtig zijn wegens het door opzet of schuld veroorzaken van de dringende reden, de werkgever is een vergoeding verschuldigd wegens de kennelijke onredelijkheid van het beëindigen van de arbeidsovereenkomst wegens die dringende reden.

\section{Wat is door de invoering van de Wwz niet anders geworden?}

De Wwz heeft verandering gebracht in de tekst van de regeling van de dringende reden, zonder dat een inhoudelijke wijziging is beoogd. De oude tekst van artikel 7:677 lid $1 \mathrm{BW}$ luidde dat ieder der partijen de bevoegdheid had de arbeidsovereenkomst onverwijld op te zeggen, maar dat de partij die dat deed zonder een dringende reden schadeplichtig was. In het arrest Schrijvers/Van Essen haalt de Hoge Raad deze bepaling aan om die vervolgens a contrario uit te leggen: in het geval één der partijen wel onverwijld opzegt met een dringende reden, is die partij geen schadevergoeding verschuldigd. Sinds de Wwz luidt de tekst van artikel 7:667 lid 1 BW anders en kent het niet meer de bevoegdheid de arbeidsovereenkomst onverwijld op te zeggen, maar alleen de bevoegdheid de arbeidsovereenkomst onverwijld op te zeggen wegens een dringende reden. Over schadeplichtigheid wordt in het artikellid niets meer gezegd, hetgeen mede vanuit de wens het

9. HR 12 februari 1999, NJ 1999, 643, JAR 1999/102 (Schrijvers/Van Essen). ontslagrecht te vereenvoudigen, begrijpelijk is. Zoals gezegd: er is geen inhoudelijke wijziging beoogd. ${ }^{10}$

Ook de regeling van de schadeplichtigheid van de werknemer die terecht op staande voet is ontslagen, is niet inhoudelijk veranderd. De partij die de wederpartij door opzet of schuld een dringende reden geeft, waarna de wederpartij wegens die dringende reden de arbeidsovereenkomst beëindigt, is aan die wederpartij de gefixeerde schadevergoeding verschuldigd. De begrippen 'opzet of schuld' hebben in de literatuur en rechtspraak relatief weinig aandacht gekregen. Kennelijk zijn ze voldoende duidelijk, althans leiden ze tot weinig problemen. ${ }^{11}$

Naar oud recht was de situatie dus niet erg ingewikkeld: als werd aangenomen dat de onverwijlde opzegging van de werkgever op een terecht en tijdig aangevoerde dringende reden was gestoeld, was de werkgever geen vergoeding aan de werknemer verschuldigd. Of de werknemer wegens het veroorzaken van die dringende reden schadeplichtig was, was afhankelijk van de vraag of de werknemer de dringende reden door opzet of schuld had veroorzaakt. In het bevestigende geval was de werknemer de gefixeerde of volledige schadevergoeding verschuldigd.

\section{Wat is door de invoering van de Wwz wel anders geworden? De transitievergoeding}

Nieuw is de transitievergoeding. Artikel 7:673 lid 1 onderdeel a onder $1^{\circ}$ en lid 7 onderdeel c BW bepalen dat de werkgever deze aan de werknemer is verschuldigd als hij de arbeidsovereenkomst opzegt, tenzij het eindigen van de arbeidsovereenkomst het gevolg is van ernstig verwijtbaar handelen of nalaten van de werknemer. Waar eerst de regering uitging van de gedachte dat bij een opzegging wegens een dringende reden de werkgever geen vergoeding verschuldigd was, werd dat later anders. Minister Asscher is (pas) in de Eerste Kamer over deze vergoeding in relatie tot een opzegging wegens een dringende reden ondervraagd en hij zei toen: 'Op zichzelf genomen verandert het wetsvoorstel niets aan de term dringende reden. De situatie die tot een dringende reden leidt, hoeft niet altijd gepaard te gaan met verwijtbaarheid. Voor ernstige verwijtbaarheid is meer nodig dan slechts een dringende reden. Het begrip dringende reden speelt een rol bij de vraag of er een grond is voor het ontslag en het begrip ernstige verwijtbaarheid bij de vraag of een aanvullende vergoeding

10. Kamerstukken // 2013/14, 33818, 3, p. 16-17. Of dat niet toch een gevolg van de wetswijziging is, kan in dit verband buiten beschouwing blijven.

11. Wel is geprocedeerd over de vraag of het aannemen van een dringende reden ook schuld dan wel opzet kan impliceren, zie HR 14 maart 2008, ECLI:NL:HR:2008:BC6641 
aan de orde is. ${ }^{12}$ Deze parlementaire gang van zaken wekt niet de indruk dat de regering goed heeft nagedacht over de gevolgen van deze mededeling, zoals dat overigens bij de behandeling van de Wwz wel meer het geval is. Sagel is uitvoerig ingegaan op de gevolgen van deze verandering van standpunt. Hij wijst erop dat de rechter nu bij iedere zaak waarbij hij een dringende reden aanneemt, zich zal moeten afvragen of die dringende reden valt in de categorie 'ernstig verwijtbaar' of in de categorie 'niet, althans niet ernstig verwijtbaar'. ${ }^{13}$ In de rechtspraak die na invoering van de Wwz is gewezen komt het voor dat een dringende reden wordt aangenomen, maar geen ernstige verwijtbaarheid van de werknemer bij het ontstaan van die dringende reden, zodat de werkgever aan de werknemer een transitievergoeding verschuldigd is. Het gaat dan om een schoonmaakster in een verzorgingshuis die drank steelt uit een kamer van een bewoner en die deswege wel terecht op staande voet wordt ontslagen, maar aan wie, nu de werkgever niet heeft aangetoond dat sprake is van ernstige verwijtbaarheid, wel een transitievergoeding wordt toegekend $^{14}$ of om een werkneemster die kampt met een alcoholprobleem. ${ }^{15}$

Daarnaast is in het achtste lid van artikel 7:673 BW voorzien in de mogelijkheid om aan de werknemer toch een transitievergoeding toe te kennen indien het niettoekennen van de transitievergoeding wegens de ernstige verwijtbaarheid van de werknemer bij het beëindigen van de arbeidsovereenkomst naar maatstaven van redelijkheid en billijkheid onaanvaardbaar is. De regering heeft laten weten dat daarbij te denken valt aan een werknemer die een relatief kleine misstap begaat na een heel lang dienstverband. ${ }^{16}$ Deze bepaling wordt een enkele keer gebruikt: zo in het geval van een docent die de antwoorden van een toets aan een leerlinge gaf 'uit een te grote betrokkenheid maar zonder eigen gewin' ${ }^{\text {'17 }}$ en in het geval een oudere werknemer met vijftien dienstjaren en een goede staat van dienst die een dringende reden veroorzaakt. ${ }^{18}$ De kantonrechter acht het ontslag op staande voet van een werknemer met een lang dienstverband die drie pennen steelt niet vernietigbaar en ernstig verwijtbaar, maar kent deze werknemer wel een gedeeltelijke transitievergoeding toe. ${ }^{19}$ Veelal wordt het verzoek om toekenning van de transitievergoeding bij een ontslag op staande voet afgewezen. Soms wordt daarbij verwezen naar de ernst van het verwijtbaar handelen. ${ }^{20}$ Ik vraag me af of die overweging voor een afwijzing dragend kan zijn en kom daarop later terug. Overigens zou het zich ook kunnen voordoen dat de werkne-

12. Handelingen $/ 2013 / 14,33818,32,14$, p. 14

13. S.F. Sagel: 'Het ontslag op staande voet en de WWz (I)', TRA 2015/45, p. 9.

14. Rb. Amsterdam 17 december 2015, ECLI:NL:RBAMS:2015:9419.

15. Rb. Overijssel, Zwolle, 25 april 2016, JAR 2016/142.

16. Kamerstukken // 2013/14, 33818, 3, p. 113

17. Rb. Zeeland-West-Brabant 23 november 2015, ECLI:NL:RBZWB: 2015:7552.

18. Rb. Noord-Holland 18 mei 2016, ECLI:NL:RBNHO:2016:9094.

19. Rb. Oost-Brabant 30 juni 2016, AR-Updates 2016-0727.

20. Gerechtshof Arnhem-Leeuwarden 18 augustus 2016, ECLI:NL:GHARL: 2016:6726 mer wel een ernstig verwijt gemaakt kan worden van de verweten gedraging, zodat de beëindiging van de arbeidsovereenkomst om die reden hem geen transitievergoeding oplevert, terwijl die gedraging wegens zijn persoonlijke of andere omstandigheden geen dringende reden oplevert. $^{21}$

\section{De beoordeling van het ontslag op staande voet en de vergoeding}

Ik vermoed dat de rechterlijke macht bij de beoordeling van de dringende reden een standaard overweging ter beschikking heeft die luidt: 'Bij de beoordeling van de vraag of van een zodanige dringende reden sprake is, moeten de omstandigheden van het geval in onderling verband en samenhang in aanmerking worden genomen. Daarbij behoren ook in de beschouwing te worden betrokken de persoonlijke omstandigheden van de werknemer, zoals diens leeftijd, de aard en duur van het dienstverband en de gevolgen van het ontslag op staande voet. Ook indien de gevolgen ingrijpend zijn, kan een afweging van de persoonlijke omstandigheden tegen de aard en de ernst van de dringende reden tot de slotsom leiden dat een onmiddellijke beëindiging van de arbeidsovereenkomst gerechtvaardigd is. ${ }^{22}$ Het is de vraag of tot de in deze standaardoverweging genoemde in aanmerking te nemen omstandigheden ook behoort de bereidheid tot betaling of de daadwerkelijke betaling van vergoedingen door de werkgever aan de werknemer bij diens ontslag op staande voet. Sagel is in zijn proefschrift op die vraag ingegaan en schrijft dat het aanbieden van een zekere betaling door de werkgever aan de op staande voet ontslagen werknemer bepaald niet hoeft af te doen aan het bestaan van een dringende reden, sterker nog: hij meent dat dat aan het bestaan daarvan kan bijdragen. Hij betoogt dat het betalen van een vergoeding de belangenafweging in het voordeel van de werkgever kan doen doorslaan, zeker in die gevallen waarin de werknemer geen verwijt van het bestaan of ontstaan van de dringende reden te maken is. ${ }^{23}$

Ik aarzel over dit standpunt. Omdat de omstandigheden van het geval in onderling verband en samenhang in aanmerking moeten worden genomen, is het lastig de aard en ernst van de door de werkgever gestelde dringende reden te onderscheiden van de persoonlijke omstandigheden van de werknemer en de gevolgen van het ontslag op staande voet. Door deze wijze van beoordelen van een dringende reden rakt een vergoeding alle

21. Gerechtshof Den Bosch 23 juni 2016, ECLI:NL:GHSHE:2016:2514

22. Zie bijvoorbeeld het hiervoor genoemde arrest en Rb. Overijssel, Zwolle, 25 april 2016, JAR 2016/142. Deze 'standaardoverweging' lijkt in belangrijke mate ontleend aan rechtsoverweging 4.4. van het arrest Schrijvers/Van Essen, waarbij mist de overweging van de Hoge Raad dat 'in de eerste plaats in de beschouwing te worden betrokken de aard en ernst van hetgeen de werkgever als dringende reden aanmerkt'.

23. Sagel 2013, p. 332-333 
omstandigheden, ook de aard en ernst van de dringende reden zelf. Het compenseren van de wellicht ernstige gevolgen van het ontslag op staande voet na een terecht aangevoerde dringende reden loopt dan snel over in het 'kopen van een dringende reden'. Dat daarvan eenvoudig sprake kan zijn, blijkt wel daar waar Sagel meent dat het nieuwe systeem als gevolg van de Wwz, waarbij de rechter door geen ernstige verwijtbaarheid aan te nemen bij een ontslag op staande voet waarvan de reden weliswaar verwijtbaar maar niet ernstig verwijtbaar is, ertoe kan leiden dat sneller dan vóór juli 2015 een dringende reden wordt aangenomen. Hij schrijft dat dit nieuwe systeem de rechter de mogelijkheid biedt tot meer maatwerk, want het biedt de rechter de mogelijkheid de scherpste randen van het ontslag af te vijlen 'door de dringende reden niet als ernstig verwijtbaar te betitelen met de transitievergoeding als gevolg'. Sagel vindt dat 'best een sympathieke ontwikkeling'. ${ }^{24}$

\section{Is het vergoeden van het ontslag op staande voet} wenselijk?

Naar mijn mening is het toekennen van een vergoeding aan de op staande voet ontslagen werknemer niet alleen maar positief te waarderen, zeker niet als dat wordt bezien in relatie tot de andere regels en de bedoeling van de Wwz. Het toekennen van een vergoeding aan de op staande voet ontslagen werknemer verhoudt zich naar mijn mening minder goed met het ontslagstelsel, het leidt ertoe dat de dringende reden om op staande voet te ontslaan verwatert en het stuurt de rechter nog meer op het glibberige pad van de beoordeling van de verschillende vormen van verwijtbaarheid. Het maakt het ontslagrecht complex en onoverzichtelijk, terwijl het nu juist de bedoeling van de wetgever met de Wwz was het ontslagrecht te vereenvoudigen en voorspelbaarder te maken. ${ }^{25}$

In het Schrijvers/Van Essen-arrest overwoog de Hoge Raad dat een kennelijk onredelijke ontslagvergoeding aan de werknemer bij een terecht verleend ontslag op staande voet zich niet laat verenigen met de in artikel 7:677 lid 2 BW voorziene mogelijkheid dat de werknemer in geval van een ontslag wegens een dringende reden jegens de werkgever schadeplichtig is. Dat argument is door de invoering van de Wwz niet weggenomen. De verschuldigdheid van een gefixeerde schadevergoeding is door de Wwz ongewijzigd gebleven. Indien nu de werkgever aan de werknemer een transitievergoeding verschuldigd is wegens het ontbreken van ernstige verwijtbaarheid, is de vraag of de werknemer niet toch door opzet en schuld een dringende reden heeft gegeven en daardoor aan de werkgever de gefixeer-

24. S.F. Sagel: 'Het ontslag op staande voet en de Wwz (I)', TRA 2015/45, p. 11.

25. Kamerstukken // 2013/14, 33818, 3, p. 7 en 8. de schadevergoeding verschuldigd is. Dit is volgens de Hoge Raad niet verenigbaar met een verplichting van de werkgever tot vergoeding van schade wegens een kennelijk onredelijke opzegging. De aard van de transitievergoeding is anders dan die van de kennelijk onredelijke ontslagvergoeding. Die laatste is een schadevergoeding, net als de gefixeerde schadevergoeding, terwijl de transitievergoeding niet in relatie tot de schade wordt vastgesteld. Het over en weer verrekenen van schadevergoedingen is minder voor de hand liggend dan het verrekenen van een (gefixeerde) schadevergoeding met een transitievergoeding. Maar als dat laatste al wel zou passen in het systeem, leidt het over en weer verrekenen van vergoedingen wel tot een toename van de complexiteit.

Om deze mogelijke onverenigbaarheid weg te nemen en de complexiteit te verminderen kan een oplossing worden gezocht in de uitleg van de begrippen 'opzet en schuld'. Het lijkt me dat nu al ernstige verwijtbaarheid samenvalt met opzet en schuld: indien de werknemer van het veroorzaken of het bestaan van de dringende reden een ernstig verwijt te maken valt, zal zeker in mijn visie van opzet of schuld sprake zijn. De mogelijke onverenigbaarheid met het stelsel en de complexiteit zou kunnen worden weggenomen als wordt aangenomen dat met die woorden hetzelfde wordt bedoeld als met 'ernstige verwijtbaarheid'. In dat geval heeft de werknemer die door ernstig verwijtbaar handelen of nalaten een dringende reden aan zijn werkgever heeft gegeven en deswege op staande voet wordt ontslagen geen recht op de transitievergoeding en is hij ten opzichte van zijn werkgever gefixeerd schadeplichtig. Als er geen sprake is van ernstige verwijtbaarheid, zou er dan ook geen sprake zijn van opzet en schuld, en heeft de werknemer recht op een transitievergoeding en de werkgever geen aanspraak op de gefixeerde schadevergoeding. Hoewel er goede argumenten zijn om deze gelijkstelling aan te nemen, biedt de tekst van de wet daarvoor iets minder aanknopingspunten. Het tweede lid van artikel 7:677 BW spreekt over 'de partij die door opzet of schuld aan de wederpartij een dringende reden heeft gegeven', hetgeen lijkt te betekenen dat er ook een dringende reden kan worden aangenomen indien er geen sprake is van opzet of schuld.

Deze oplossing alleen doet onvoldoende recht aan de overwegingen van de Hoge Raad en de standaardoverwegingen van de lagere rechters, waaruit nu juist blijkt dat de omstandigheden die reden kunnen zijn om te denken aan een vergoeding, dienen te worden betrokken bij de vraag of sprake is van een terecht aangevoerde dringende reden. Als de werkgever door betaling van een (transitie)vergoeding een deel van die omstandigheden naar zijn hand kan zetten, kan hij daarmee eenvoudiger een dringende reden genereren. Zeker nu door de Wwz een gesloten stelsel van ontslaggronden is geschapen en de dringende reden op zichzelf in die bijt een vreemde eend is, is er weinig reden te denken dat meer ruimte om wegens een dringende reden op staande voet de arbeidsovereenkomst te beëindigen door de wetgever is beoogd. Integendeel: uitgangspunt is juist dat het ont- 
slag op staande voet een uitzondering is. Een stelsel waarbij het niet de vraag is of een ontslag op staande voet moet worden verleend hoewel het voor de werknemer zulke ernstige gevolgen heeft (zo zielig is), maar de vraag is welk bedrag bij dat ontslag op staande voet redelijk is, ligt niet binnen het bereik van de huidige wetgeving en rechtspraak en evenmin binnen mijn rechtvaardigheidsgevoel. Anders gezegd: een ontslag op staande voet is een uitzonderlijke wijze van beëindigen van de arbeidsovereenkomst en de regels die het ontslag op staande voet wegens een dringende reden mede bepalen zouden niet in de richting van het faciliteren van een dergelijk ontslag moeten worden gezet, tenzij de wetgever daarvoor hele duidelijke anwijzingen geeft. De wetgever heeft dat niet gedaan maar ook niet willen doen, eerder integendeel. Een dringende reden is tenslotte niet te koop.

Bij een stelsel waarbij het ontslag op staande voet gepaard kan gaan met een vergoeding komen de eerdere bezwaren die zijn aangevoerd tegen de beoordeling van de verwijtbaarheid van het ontstaan of bestaan van een dringende reden in volle omvang terug. Waar in het kader van de beoordeling van de dringende reden voor invoering van de $\mathrm{Wwz}$ de verwijtbaarheid als vereiste buiten beeld bleef en slechts als belangrijk gezichtspunt zou kunnen worden betrokken omdat de rechter zich daarmee op een glibberig pad zou begeven, dient de rechter dat pad in dit stelsel na de Wwz geheel af te leggen. ${ }^{26} \mathrm{Er}$ is immers een heel spectrum van verwijtbaarheden en als de rechter zich daarover, nadat de ernst van de dringende reden door de werkgever is gesteld en bewezen in het kader van de beoordeling van de vraag of de dringende reden terecht tot een ontslag op staande voet heeft geleid, alsnog moet buigen om de vraag te beantwoorden of desalniettemin een transitievergoeding verschuldigd is ${ }^{27}$ en of er sprake is van opzet of schuld, dan is dat pad zo glibberig dat de werkgever wel bijna onderuit moet gaan. Het ligt dan meer voor de hand de ernstige verwijtbaarheid maar één keer te beoordelen en wel in het kader van het bestaan van de dringende reden.

Vervolgens dient in het systeem van de wet ook lid 8 van artikel 7:673 $\mathrm{BW}$ te worden betrokken. Indien wordt vastgesteld dat de werknemer de transitievergoeding wegens ernstig verwijtbaar handelen niet toekomt (artikel 7:673 lid 7 onderdeel c BW) komt pas de vraag aan de orde of het niet toekennen van de transitievergoeding naar maatstaven van redelijkheid en billijkheid onaanvaardbaar is. Dekker ${ }^{28}$ schrijft dat de wetgever juist met dit lid de rechter de ruimte voor maatwerk biedt. In zijn visie dient eerst te worden beoordeeld of er sprake is van

26. Zie over de moeilijkheden om bij ontbinding wegens de e-grond het onderscheid tussen verwijtbaar en ernstig verwijtbaar te maken: E. Wies en M.A. Schneider: 'Verwijtbaar handelen of nalaten van de werknemer ('e-grond'): een analyse van de rechtspraak onder de Wwz', ArbeidsRecht 2016/28.

27. Rb. Amsterdam 17 december 2015, ECLI:NL:RBAMS:2015:9419, onder verwijzing naar Sagel 2015.

28. F.M. Dekker, commentaar bij Rb. Zeeland-West-Brabant 23 november 2015, TRA 2016/25. ernstige verwijtbaarheid om vervolgens, bij bevestigende beantwoording, te beoordelen of het naar maatstaven van redelijkheid en billijkheid onaanvaardbaar is dat de werknemer geen transitievergoeding toekomt. Dekker meent dat bij de eerste vraag (heeft de werknemer ernstig verwijtbaar gehandeld) de focus moet liggen op de vraag waarom de arbeidsovereenkomst tot een einde komt. Bij de beantwoording van die vraag ziet hij geen ruimte om die aspecten in de beoordeling te betrekken die niet samenhangen met de ontslagreden, zoals het functioneren van de werknemer, diens leeftijd en de diensttijd. Deze aspecten dienen in zijn visie pas bij de beantwoording van de vraag of het naar maatstaven van redelijkheid en billijkheid onaanvaardbaar is om de werknemer geen transitievergoeding toe te kennen, te worden betrokken. Dat zou dan leiden tot een andere beoordeling van de dringende reden. Deze visie zou betekenen dat waar de beoordeling van de dringende reden om een beschouwing van alle omstandigheden van het geval vraagt, de beoordeling van de ernstige verwijtbaarheid alleen vraagt om een beschouwing van de reden die tot het einde van de arbeidsovereenkomst leidt. Is deze reden de werknemer ernstig verwijtbaar, dan kan de werkgever de arbeidsovereenkomst beëindigen. Dekker gaat niet in op de vraag of dat die ernstige verwijtbaarheid dan ook zonder meer tot een dringende reden maakt. Hoewel ik het betoog van Dekker wetssystematisch kan plaatsen, lijkt me deze wijze van het afzonderlijk beoordelen van samenhangende aspecten erg moeilijk en alleen daarom al onwenselijk. Bij de beoordeling van de vraag of sprake is van een dringende reden dienen alle omstandigheden in samenhang te worden betrokken, ook de persoonlijke omstandigheden van de werknemer.

\section{Wat dan wel? Dringende reden $=$ ernstig verwijtbaar = opzet en schuld?}

De hiervoor behandelde bezwaren tegen een systeem waarbij de terecht op staande voet ontslagen werknemer toch een transitievergoeding kan worden toegekend pleiten ervoor de rechtspraak dat voor een ontslag op staande voet wegens een dringende reden bij het ontstaan en bestaan van de dringende reden geen verwijtbaarheid aan de zijde van de werknemer is vereist, te heroverwegen. Indien wordt aangenomen dat alleen een dringende reden, die tot een terecht ontslag op staande voet kan leiden, bestaat als de werknemer een ernstig verwijt te maken valt van die dringende reden, wordt tegemoetgekomen aan de bezwaren. Het ontslag wordt daardoor eenvoudiger en voorspelbaarder en dat waren juist belangrijke doelstellingen van de wet. Die doelstellingen worden niet bereikt door het uiteentrekken van juridische begrippen en beoordelingen.

Er zijn ook andere goede argumenten om vast te houden aan het uitgangspunt dat het beëindigen op staande voet 
van de arbeidsovereenkomst zonder vergoeding aan de werknemer dient te geschieden. Het sluit beter aan bij het systeem van het ontslagrecht, ook na invoering van de $W_{w z}$, en het voorkomt de in de literatuur gevoelde ruimte om een gebrek in de dringende reden te dichten met een vergoeding. Het ontslag op staande voet dient een uitzondering te blijven. Voor de aan alcohol verslaafde werkneemster die van de diefstal van alcohol van verzorgden geen ernstig verwijt te maken valt, maar die wel wegens een door haar handelen veroorzaakte dringende reden op staande voet kan worden ontslagen, geldt dan dat het van tweeën één is: óf de diefstal is haar ernstig te verwijten in welk geval ze terecht op staande voet wordt ontslagen zonder dat haar een vergoeding wordt toegekend en zij zelf gefixeerd schadeplichtig is, óf er is geen sprake van een dringende reden. In dat laatste geval kan de werkgever ongetwijfeld de arbeidsovereenkomst wegens verwijtbaar handelen laten ontbinden, waarbij de werkneemster recht heeft op een transitievergoeding. De regering wijst ook uitdrukkelijk op deze laatste mogelijkheid in het geval dat de werknemer twijfelt of er sprake is van een dringende reden. ${ }^{29}$

De ruimte om de transitievergoeding geheel of gedeeltelijk toch toe te kennen indien de niet-toekenning naar maatstaven van redelijkheid en billijkheid onaanvaardbaar is, past ook goed in dit stelsel. De transitievergoeding dient immers twee doelen: het is bedoeld als compensatie voor het verlies van de arbeidsplaats en het is bedoeld om de transitie van de werknemer naar een andere baan te vergemakkelijken. Gelet op dat laatste vergoedt de transitievergoeding de arbeidsmarktkosten die de werknemer moet maken. ${ }^{30}$ Indien de werknemer ernstig verwijtbaar heeft gehandeld en deswege de arbeidsovereenkomst wordt beëindigd, ligt het niet voor de hand om hem te compenseren voor het verlies van zijn dienstbetrekking. Maar het kan zo zijn dat de werkgever gedurende het dienstverband onvoldoende inspanningen heeft verricht om de werknemer toe te rusten op de arbeidsmarkt en de werknemer na het ontslag op staande voet daarom extra kosten moet maken om een transitie te kunnen maken of daardoor onevenredig lang werkloos zal zijn. In dat geval zal het niet (gedeeltelijk) toekennen van de transitievergoeding naar maatstaven van redelijkheid en billijkheid onaanvaardbaar kunnen zijn en lid 8 biedt dan de ruimte om toch tot (gedeeltelijke) toekenning van de transitievergoeding over te gaan.

\section{Conclusie}

De huidige rechtspraak gaat ervan uit dat van het ontstaan of bestaan van een dringende reden niet aan de werknemer een verwijt hoeft te worden gemaakt, om hem deswege toch op staande voet te kunnen ontslaan. Deze rechtspraak leidt tot de conclusie dat, anders dan onder het oude recht, bij het ontslag op staande voet van de werknemer tevens moet worden beoordeeld of de werknemer de dringende reden niet ernstig valt te verwijten, in welk geval hem een transitievergoeding toekomt. In de rechtspraak wordt van die ruimte ook gebruik gemaakt. Dit alles is een breuk met het oude recht, waarin de terecht op staande voet ontslagen werknemer geen vergoeding toekwam. Dat dit nu wel lijkt te kunnen, lijkt niet te berusten op een doordachte keuze van de wetgever. Integendeel, het compliceert het ontslagrecht eerder dan dat het dit vereenvoudigt. Ook systematisch lijkt de figuur dat de werknemer een vergoeding wegens een terecht ontslag op staande voet toekomt, minder wenselijk. Om alle bezwaren die tegen deze figuur gelden het hoofd te bieden, ligt het meer voor de hand onder de Wwz aan te nemen dat een dringende reden om de werknemer op staande voet te ontslaan alleen kan worden aangenomen indien de werknemer van het ontstaan en bestaan van die dringende reden een ernstig verwijt kan worden gemaakt. 